\title{
Determinants of Customer Satisfaction and eWOM in the Sharing Economy: Timeshare versus Peer-to-Peer Accommodations
}

\author{
Jennifer Redditt *, Marissa Orlowski ${ }^{(}$, Alan Fyall, Amy M. Gregory and Heejung Ro \\ Rosen College of Hospitality Management, University of Central Florida, Orlando, FL 32819, USA; \\ marissa@mvhospitalitysolutions.com (M.O.); alan.fyall@ucf.edu (A.F.); amy.gregory@ucf.edu (A.M.G.); \\ heejung.ro@ucf.edu (H.R.) \\ * Correspondence: jenredditt@knights.ucf.edu
}

\begin{abstract}
This study aims to investigate the differential effects of determinants of satisfaction on subsequent electronic word-of-mouth (eWOM) behavior in the sharing economy with peer-to-peer accommodations and timeshares. Data were collected from consumers who stayed at either a timeshare or peer-to-peer accommodation within the previous year $(\mathrm{N}=785)$. Structural equation modeling was used to test the relationship between the determinants and eWOM through satisfaction, followed by multiple-group comparison to examine the moderating effect of accommodation type. The results indicated that amenities, economic benefits, and trust demonstrated an indirect effect on eWOM behavior through satisfaction, but community belonging affected eWOM behavior directly. Multiple-group SEM revealed that accommodation type moderated the indirect effects of community belonging, economic benefits, and trust on eWOM behavior, such that the indirect effect was significant only for timeshare accommodations. This study contributes to the sharing economy literature by filling the gap of lodging research beyond Airbnb and including timeshares. The findings highlight competitive differences that influence eWOM between peer-to-peer accommodations and timeshares that otherwise offer similar home-like accommodations. The study revealed a newly found direct relationship between community belonging and eWOM.
\end{abstract}

Citation: Redditt, J.; Orlowski, M.; Fyall, A.; Gregory, A.M.; Ro, H. Determinants of Customer Satisfaction and eWOM in the Sharing Economy: Timeshare versus Peer-to-Peer Accommodations. Tour. Hosp. 2022, 3, 225-242. https:// doi.org/10.3390/tourhosp3010016

Academic Editor: Marion Joppe

Received: 4 January 2022

Accepted: 9 February 2022

Published: 15 February 2022

Publisher's Note: MDPI stays neutral with regard to jurisdictional claims in published maps and institutional affiliations.

Copyright: (c) 2022 by the authors. Licensee MDPI, Basel, Switzerland. This article is an open access article distributed under the terms and conditions of the Creative Commons Attribution (CC BY) license (https:// creativecommons.org/licenses/by/ $4.0 /)$.

Keywords: sharing economy; eWOM; satisfaction; community belonging; timeshare; peer-to-peer accommodations

\section{Introduction}

In recent years, the sharing economy has emerged as a notable phenomenon of the lodging industry that elicits unique consumer behaviors and themes (e.g., [1-3]). The growth of peer-to-peer (P2P) accommodations in the sharing economy, encompassing budget travelers as well as high-end consumers who are seeking local experiences, is a "game changer" which has a critical impact on other accommodation types [4]. For example, timeshares are considered as an important part of the sharing economy $[3,5,6]$ and a 10.5 billion USD industry, with 9.9 million U.S. households owning a timeshare [7]. While the sharing economy is an extensive concept that includes both timeshare stays and P2P accommodation sharing, consumer research literature is still developing and thus relatively little is known about the timeshare area of the sharing economy [5].

Timeshare stays can be considered an important part of the sharing economy for several reasons. First, the concept of timeshare stays began in Europe in 1964 with consumers sharing ownership of a vacation home in the Swiss Alps for use during different periods of time [8]. Second, Lamberton and Rose [3] specifically consider timeshare stays as part of the open commercial goods sharing typology as one of their quadrants in the sharing economy with lower exclusivity and higher rivalry. Third, prior studies consider timeshare stays as part of the sharing economy due to the nature of providing short-term access to the accommodations [6]. Dredge and Gyimóthy [6] described the sharing economy in terms of temporary access to goods where timeshares and temporary office space in hotels were 
specifically provided as examples within the hospitality industry. Bardhi and Eckhart [5] describe the sharing economy as access-based with market mediation being non-profit and for-profit, such as Airbnb and Vrbo, where rooms or houses are rented. They consider timeshares to be part of the sharing economy owing to the shared benefits and shared sense of ownership and suggested further studies to compare timeshare stays and P2P sharing. Nevertheless, timeshares are an under-researched lodging segment. As the industry has morphed to meet consumer demand, previous studies are found to be outmoded [9].

Eckhardt et al. [10] (p. 18) noted a limited amount of research related to satisfaction in sharing economy literature and proposed the question for future research, "What drives customer satisfaction in the sharing economy?". They further mentioned that sharing economy literature tends to focus on a specific firm, such as Airbnb, rather than an industry segment. Kuhzady et al. [11] conducted a review of P2P accommodation literature from 2000 to 2019, finding most literature focused on Airbnb and remarked a gap in literature related to socio-cultural issues such as community belonging. Mody et al. [12] and Prayag and Ozanne [13] conducted P2P accommodation literature reviews and found most noticeably that eWOM was not mentioned, indicating a gap for further research. Moreover, Gregory and Weinland's [14] literature review of forty years of timeshare research revealed a significant gap in the literature related to electronic word-of-mouth (eWOM) studies. Further, Tussyadiah and Zach [15] have called for further research comparing P2P accommodations with other accommodation types. The impetus for this comparison is supported by Chen and Xie [16], who found consumer valuations of Airbnb listings to be based on amenities that were in direct competition with resort offerings such as timeshares. Additionally, Dann et al.'s [17] Airbnb literature review suggested that hospitality operators (including timeshares) promote their competitive advantages over Airbnb in line with their customers' desires.

Thus, the main objective of the current study is to investigate the differential effects of known determinants of satisfaction on subsequent eWOM behavior for the users of accommodation sharing. Building on prior research and grounded in collaborative consumption theory, the subordinate research objectives of this study are threefold: (1) to test the effects of five known determinants of satisfaction in the specific context of timeshare stays and P2P accommodation sharing, (2) to examine the mediating role of satisfaction between these determinants and eWOM, and (3) to assess the moderating effect of accommodation type.

The findings of this study contribute to sharing economy literature by providing insights into the competitive advantages and similarities between two important lodging products and filling an important gap relative to our understanding of eWOM. Beyond offering academic and theoretical implications, this study also offers practical implications for timeshare developers, hoteliers, and proprietors of P2P accommodations. Specifically, it presents actionable recommendations for timeshare companies competing with this disruptive lodging product in an intensely competitive industry. Dogru et al. [18] contend that the exponential growth of P2P accommodations, specifically Airbnb, across all lodging segments is a significant threat to the entire lodging industry. The study of Airbnb's impact on hotel sales revealed that "differentiation is key for success in today's competitive lodging landscape" [19] (p. 91). This study will unveil these competitive differences between P2P and timeshare accommodations. Timeshare industry executives have noted that current marketing practices are one of the areas likely to have the greatest impact on the industry [14]. The value to practitioners of understanding the factors influencing eWOM is attributed to its role in affecting purchase decisions in the lodging industry [20]. Thus, this study provides competitive intelligence to timeshare practitioners about eWOM that can shape their marketing strategies and ultimately influence sales.

\section{Literature Review}

\subsection{The Sharing Economy}

The sharing economy has been defined as "the peer-to-peer-based activity of obtaining, giving, or sharing the access to goods and services, coordinated through community-based 
online services" [21] (p. 2047). The business model provides a social exchange between consumers who have available lodging space for other consumers to rent who are in need of lodgings in that location [22]. Like P2P accommodation sharing in private homes and apartments, the timeshare product offering is diverse and includes a variety of unit sizes ranging from studios to three-bedroom units [23].

Dredge and Gyimóthy [6] consider that timeshares are included in the sharing economy based on the idea that short-term usage of goods are evolving to become more beneficial than owning goods. Bardhi and Eckhart [5] (p. 896) consider that in the context of "timeshare housing, individuals continue to hold full property rights under fractional ownership modes; however, the benefits and obligations are shared with others, and a shared sense of ownership exists [24]". Thus, either as an owner sharing communal rights to a timeshare interest [5] or as an owner renting out their timeshare interest to others, timeshare stays are considered an element of the sharing economy.

\subsection{Collaborative Consumption Theory}

To promote further theoretical development related to sharing economy accommodations, this study explored the determinants of satisfaction and eWOM within the framework of collaborative consumption theory. The participation in and intention to purchase in the sharing economy evolves from collaborative consumption theory [25]. Collaborative consumption as defined by Belk [25] (p. 1597) describes the sharing economy as "people coordinating the acquisition and distribution of a resource for a fee or other compensation". Dredge and Gyimóthy [6] assert that collaborative consumption was first pioneered by Felson and Speath [26] and their studies of group consumer behavior, where they determined jointly purchasing a pitcher of beer was more efficient than separate glasses. However, their research did not incorporate web-based platforms as it was 1978 and many years before the Internet. Later, Botsman and Rogers [1] assumed the phrase collaborative consumption to describe the sharing economy in terms of "traditional sharing, bartering, lending, trading, renting, gifting and swapping, redefined through technology and peer communities" [1] (p. XV).

Studies have explored amenities, community belonging, economic benefits, trust, and vacation counselor/host in the sharing economy within the context of collaborative consumption [27,28]. Möhlmann [27] (p. 194) referenced Bardhi and Eckhardt [5], Botsman and Rogers [1], and Owyang [29] in her discussion of collaborative consumption, whereby consumers participate in organized networks and engage in sharing by "renting, lending, trading, bartering, and swapping of goods, services, transportation solutions, space, or money". Möhlmann's [27] study does not include gift giving but rather discusses transactions between consumers or between consumers and businesses where compensation is involved in a non-ownership exchange.

By utilizing the collaborative consumption definition of the sharing economy, the exchange relationship is more broadly defined and can encompass both consumer-toconsumer and business-to-consumer instances. Based on this broader definition, the current study included two distinct forms of accommodation sharing products. P2P accommodation sharing, such as the rental of homes and apartments through consumer-to-consumer sites (e.g., Airbnb, Homeaway.com (accessed on 2 January 2022), Vrbo.com (accessed on 2 January 2022)), represents what Botsman and Rogers [1] consider the "traditional" sharing economy. Comparatively, timeshare stays encompass a business-to-consumer relationship with an owner sharing communal rights to a timeshare interest sold by a timeshare developer, which Lamberton and Rose [3] described as the open commercial goods sharing typology in the sharing economy. Further, in the context of collaborative consumption theory, timeshares provide a short-term usage of goods with benefits and obligations shared with others $[5,6,24]$. Additionally, timeshare stays can be P2P/consumer-to-consumer directly from an owner to a consumer through Homeaway.com or Vrbo.com or through a third-party business on behalf of the owner such as through an HOA or developer via Homeaway.com (accessed on 2 January 2022) [30]. 


\subsection{Determinants of Sharing Economy Satisfaction}

In Möhlmann's [27] study, various factors were considered as determinants for satisfaction with sharing economy accommodation: community belonging, cost savings, environmental impact, familiarity, internet capability, service quality, smartphone capability, trend affinity, trust, and utility. Of these factors, only cost savings, familiarity, trust, and utility were found to be significant. A P2P accommodation study by Xu et al. [31] of Airbnb reviews found that amenities had the strongest influence on satisfaction compared to other variables. Shin et al. [32] conducted a ten-year meta-analysis of satisfaction related to P2P in hospitality and tourism literature, which revealed trust and value for money had relationships with satisfaction. Community belonging, meanwhile, was partially supported in both Tussyadiah's [33] and Möhlmann's [27] studies. Gregory et al.'s [34] study revealed that resort amenities and a vacation counselor contributed to customer satisfaction during a timeshare stay. Based on the aforementioned literature, we developed a conceptual framework with five determinants posited to lead to sharing economy lodging satisfaction: amenities, community belonging, economic benefits, vacation counselor/host, and trust. The conceptual model for this study is presented in Figure 1.

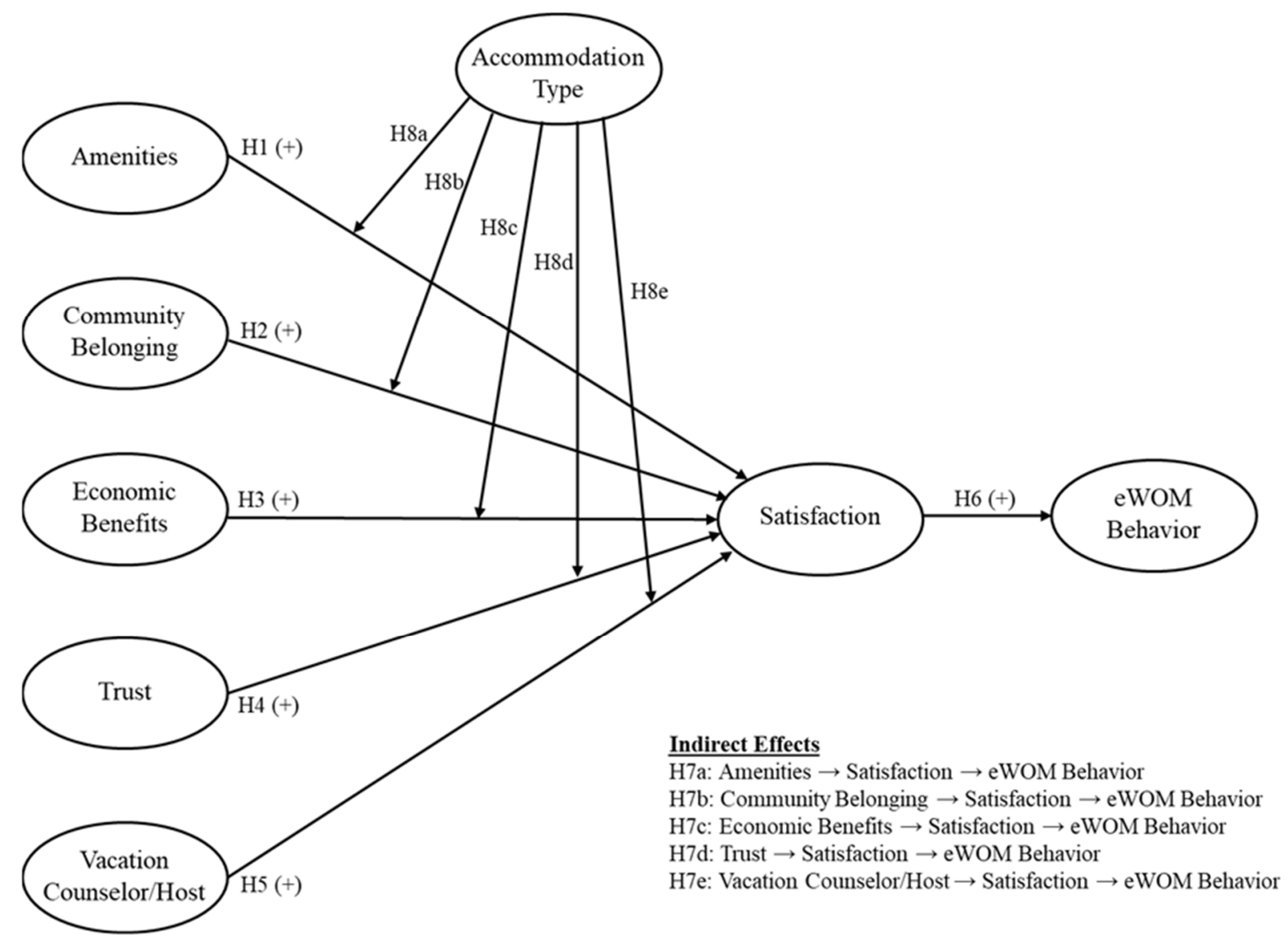

Figure 1. Conceptual model.

\subsection{Amenities}

An amenity is considered to be an extra service or product provided to guests by the accommodation provider, usually without an extra charge [35]. Sharing economy lodging amenities also include home-like amenities, including a full kitchen, washing machine, and dryer [36]. Both Xu et al.'s [31] and Luo and Tang's [37] studies of Airbnb reviews indicated that amenities influenced satisfaction. Timeshare companies provide a broad array of amenities that serve the vacation needs of varying consumer segments [38]. Gregory et al. [34] conducted a study of timeshare product attributes' effect on customer 
satisfaction, revealing that resort amenities contributed to customer satisfaction during a timeshare stay. Further, measuring satisfaction with timeshare amenities is critical in securing market penetration [39]. Therefore, we hypothesize the following:

Hypothesis 1 (H1). Amenities have a positive impact on sharing economy lodging satisfaction.

\subsection{Community Belonging}

Botsman and Rogers [1] (p. XX) suggest that a key driver to the sharing economy is a "renewed belief in the importance of community". Sundararajan [40] commented that humans naturally search for connections with others, and this is a motivation for using sharing economy accommodations. Tussyadiah and Pesonen [41] contend the use of P2P accommodations stems from the economic benefits and social benefits of developing relationships and belonging with the local community. Prior research has found community belonging to be a determinant in participating in the sharing economy [27]. In the context of P2P, Mody et al. [42] found respondents who stayed in an Airbnb had a greater experience in relation to community belonging than those who stayed at a hotel. In the context of timeshares, Sparks et al. [43] found the social value of meeting and socializing with other timeshare owners enhanced their derived value of the timeshare stay. As a result, the following is proposed:

Hypothesis 2 (H2). Community belonging has a positive impact on sharing economy lodging satisfaction.

\subsection{Economic Benefits}

The sharing economy provides an economic benefit to consumers by renting goods at a lower cost than through traditional suppliers [44]. Collaborative consumption has been described as a rational consumer behavior that maximizes the utility of goods by replacing ownership with a lower cost alternative [21]. Poon and Huang's [45] study of Airbnb users lends support to the perception that Airbnb has more competitive pricing compared to hotels. Tussyadiah [33] found that economic benefits have a significant relationship with sharing economy accommodation satisfaction and future intention to use sharing economy accommodations. In the timeshare context, Powanga and Powanga [46] conducted an economic analysis of timeshare ownership that revealed that over a ten-year period it was more economically advantageous to purchase a timeshare with equity (USD 31,000 ) than comparable hotel stays (USD 39,000). Bardhi and Eckhardt [5] emphasize economic benefits often exceed other determinants as consumers feel savvy by renting a product they could not otherwise afford, which is particularly relevant in the timeshare space where consumers may not be able to afford owning a second home, but they can share the expense and asset with others. Jiang et al.'s [47] study of sharing economy accommodation guests found that economic value had a positive influence on customer satisfaction. Therefore, we propose the following:

Hypothesis 3 (H3). Economic benefits have a positive impact on sharing economy lodging satisfaction.

\subsection{Trust}

Trust has been defined as "a generalized expectancy held by an individual that the word, promise, or statement of another individual can be relied upon" [48] (p. 651). In collaborative consumption, Botsman and Rogers [1] consider trust as a key foundational principle. So et al. [49] found that lack of safety measures with Airbnb had a negative influence on future behavioral intentions. In the timeshare industry, Kaufman et al. [50] equated trust, along with credibility and consumer confidence, with the entrance of branded hotel chains. Möhlmann's [27] study of commercial car sharing and P2P accommodations found that trust had a positive influence on satisfaction in both studies. In addition, 
Shin et al. [32] found trust had a relationship with satisfaction in their 10-year metaanalysis of satisfaction related to P2P accommodations in hospitality and tourism literature. Collectively, these previous findings led to the following hypothesis:

Hypothesis 4 (H4). Trust of the host (timeshare brand or individual) has a positive impact on sharing economy lodging satisfaction.

\subsection{Vacation Counselor/Host}

In P2P accommodations, a vacation counselor may be considered a "host" living in the accommodation with the guest or managing the lodging as a rental property [36]. In the timeshare context, a vacation counselor may be referred to as the concierge. Gregory et al. [34] (p. 57) referred to vacation counselors as "the opportunity to speak with someone directly to help with reservations, options, product usage". This study considers "vacation counselor" to be synonymous with "host" in the P2P accommodation context and concierge or guest services in the timeshare context, specifically, individuals who provide a personalized service which facilitates vacations. Tussyadiah's [28] study on the drivers of collaborative consumption in travel found that the authenticity of staying with locals was a reason for choosing P2P accommodations. Recent studies by Ju et al. [51] and Wang and Jeong [52] found that the host was a key driver in satisfaction with P2P accommodation stays due to the personalized services provided. Xu et al.'s [31] study also found the friendliness of the vacation counselor to influence satisfaction with sharing economy lodging stays. Hence, we hypothesize the following:

Hypothesis 5 (H5). A vacation counselor/host has a positive impact on sharing economy lodging satisfaction.

\subsection{Sharing Economy Lodging Satisfaction and eWOM}

Customer satisfaction has been identified as fundamental to encouraging positive postpurchase behavior, such as positive word-of-mouth, and repeat visitation that ultimately assists in producing loyalty by retaining customers [53]. Litvin et al. [20] define eWOM as "all informal communications directed at consumers through Internet-based technology related to the usage or characteristics of particular goods and services, or their sellers" ( $\mathrm{p}$. 461). Kimmel and Kitchen [54] consider eWOM to be the most powerful online media that instantly spread to consumers around the world.

In the lodging industry, Yen and Tang [55] included hotel satisfaction as part of hotel attribute performance and found that it influenced extraversion and dissonance reduction motivations related to eWOM. Further, de Matos and Rossi [56] conducted an extensive meta-analysis of word-of-mouth antecedents and found satisfaction to have a strong relationship with word-of-mouth communications. In the timeshare context, Lawton et al. [57] found that satisfaction with their timeshare was a reason to recommend to others. Johnson and Neuhofer's [58] and Camilleri and Neuhofer's [59] studies of guest and host co-creation experiences in sharing economy accommodations suggest that positive stays result in online recommendations. Thus, we hypothesize the following:

Hypothesis 6 (H6). Sharing economy lodging satisfaction has a positive effect on eWOM behavior.

Literature also offers evidence supporting the role of satisfaction as the linking mechanism between several different factors and eWOM behavior. For example, Ha and Im [60] found satisfaction to be a mediator between pleasure and eWOM intention regarding online consumers' enjoyment of their shopping experience with a web site. Satisfaction was also found to indirectly influence the effects of both information quality and e-service quality of web sites on eWOM when booking homestays in Malaysia [61]. Thus, within the context of the sharing economy and accommodations, a mediating role of customer satisfaction might be logically anticipated. As a result, the following hypotheses are proposed: 
Hypothesis 7 (H7) (a-e). The relationship between (a) amenities, (b) community belonging, (c) economic benefits, (d) trust, and (e) vacation counselor/host and eWOM behavior is mediated by sharing economy lodging satisfaction.

\subsection{Sharing Economy Accommodation Type Differences: Timeshare vs. P2P}

A study by Tussyadiah and Zach [15] compared P2P accommodation rentals to hotel stays and found that their differences provide significant advantages for both hotels and P2P accommodation rentals. Tussyadiah and Zach [15] called for further research to compare P2P accommodations with other lodging types. As a hybrid of a P2P accommodation and a resort hotel, and an element of the sharing economy, timeshares are appropriate for such a comparison. In addition, it is critical for timeshare developers to understand their competitive advantage compared to P2P accommodations as Dann et al. [17] study suggested. Based on the findings from prior studies of differences in the relative value of various attributes between hotels and P2P accommodation sharing, we propose there will be differences between timeshares and P2P accommodations. Formally stated:

Hypothesis 8 (H8) (a-e). Accommodation type (timeshare vs. P2P) moderates the indirect effects of (a) amenities, (b) community belonging, (c) economic benefits, (d) trust, and (e) vacation counselor/host on eWOM through sharing economy lodging satisfaction.

\section{Materials and Methods}

\subsection{Sample and Data Collection}

The target population for this study was consumers who have participated in sharing economy lodging accommodations. The sampling frame was composed of individuals who have stayed in either a timeshare or P2P accommodation within the prior year. To collect data, an online survey was hosted on the Qualtrics survey platform. Participants were recruited from two sources: a timeshare company headquartered in Orlando with properties in the U.S. and Canada and Amazon Mechanical Turk (mTurk). Permission was obtained to distribute the survey link via an email to the timeshare company's database of timeshare owners, while mTurk was utilized to collect data from P2P users as we were unable to obtain similar permission and access to a P2P database (e.g., Airbnb or VRBO). For both methods of data collection, respondents were required to be 18 years of age or older, and a screening question was included to ensure respondents had stayed in a timeshare or P2P accommodation within the previous year. Participants recruited from mTurk were compensated USD 0.75 for their participation. A total of 1129 responses (666 timeshare; $463 \mathrm{P} 2 \mathrm{P}$ ) were collected and 224 (170 timeshare; $54 \mathrm{P} 2 \mathrm{P}$ ) were removed for failure to meet the study criteria. An additional 120 responses (109 timeshare; 11 P2P) were eliminated due to extensive missing data, leaving a final useable sample of 785 (387 timeshare; 398 P2P).

\subsection{Measures}

The survey was developed from scales utilized in previous studies. Specifically, we adapted measures for amenities (four items [33]), community belonging (five items [27,42], economic benefits (four items [33]), trust (six items [27]), vacation counselor/host (three items [42]), satisfaction (three items [27]), and eWOM (six items [55]). All 31 items were measured on a seven-point Likert scale $(1=$ strongly disagree; $7=$ strongly agree). The survey also included items designed to measure respondents' usage of sharing economy accommodations and basic demographic questions.

\section{Results}

\subsection{Respondent Profile}

Of the 785 respondents, 387 (49.3\%) used timeshare accommodations and 398 (50.7\%) used P2P accommodations. Table 1 summarizes additional demographic and sharing accommodation usage behaviors of the respondents, divided by accommodation type. The demographic profiles of the respective groups were very similar to the profiles reported 
in prior studies of timeshare owners (Gregory et al. [34], Upchurch and Gruber [38]) and users of P2P accommodations (Hamari et al. [21], Tussyadiah [28]).

Table 1. Respondent profile.

\begin{tabular}{|c|c|c|c|c|}
\hline \multirow{2}{*}{ Demographic Category } & \multicolumn{2}{|c|}{ Timeshare Group } & \multicolumn{2}{|c|}{ P2P Group } \\
\hline & $(\mathrm{N}=387)$ & $\%$ & $(N=398)$ & $\%$ \\
\hline \multicolumn{5}{|l|}{ Gender } \\
\hline Male & 177 & $45.7 \%$ & 185 & $46.5 \%$ \\
\hline Female & 203 & $52.5 \%$ & 210 & $52.8 \%$ \\
\hline Other & 0 & $0.0 \%$ & 2 & $0.5 \%$ \\
\hline Prefer to not answer & 7 & $1.8 \%$ & 1 & $0.2 \%$ \\
\hline \multicolumn{5}{|l|}{ Age } \\
\hline $18-24$ & 0 & $0.0 \%$ & 24 & $6.1 \%$ \\
\hline $25-34$ & 1 & $0.5 \%$ & 186 & $47.4 \%$ \\
\hline $35-44$ & 11 & $5.5 \%$ & 113 & $28.8 \%$ \\
\hline $45-54$ & 23 & $11.6 \%$ & 43 & $11.1 \%$ \\
\hline $55-64$ & 63 & $31.7 \%$ & 20 & $5.1 \%$ \\
\hline $65-87$ & 101 & $50.7 \%$ & 6 & $1.5 \%$ \\
\hline \multicolumn{5}{|l|}{ Income } \\
\hline Under $\$ 30,000$ & 6 & $1.6 \%$ & 60 & $15.1 \%$ \\
\hline$\$ 30,000-\$ 49,999$ & 6 & $1.6 \%$ & 102 & $25.6 \%$ \\
\hline$\$ 50,000-\$ 69,999$ & 33 & $8.7 \%$ & 80 & $20.1 \%$ \\
\hline$\$ 70,000-\$ 89,999$ & 58 & $15.2 \%$ & 57 & $14.3 \%$ \\
\hline$\$ 90,000-\$ 109,999$ & 60 & $15.7 \%$ & 40 & $10.0 \%$ \\
\hline$\$ 110,000-\$ 129,999$ & 28 & $7.3 \%$ & 25 & $6.3 \%$ \\
\hline$\$ 130,000-\$ 149,999$ & 28 & $7.3 \%$ & 13 & $3.3 \%$ \\
\hline$\$ 150,000$ or more & 62 & $16.3 \%$ & 14 & $3.5 \%$ \\
\hline Prefer to not answer & 100 & $26.3 \%$ & 7 & $1.8 \%$ \\
\hline \multicolumn{5}{|l|}{ Last Stay } \\
\hline Less than 6 months & 283 & $73.1 \%$ & 226 & $56.8 \%$ \\
\hline 6 Months-1 Year & 104 & $26.9 \%$ & 172 & $43.2 \%$ \\
\hline \multicolumn{5}{|l|}{ Frequency of Stay } \\
\hline Once a year & 0 & $0.0 \%$ & 129 & $32.4 \%$ \\
\hline Twice a year & 121 & $31.3 \%$ & 139 & $34.9 \%$ \\
\hline 3-4 times a year & 231 & $59.7 \%$ & 109 & $27.4 \%$ \\
\hline $5+$ times a year & 35 & $9.0 \%$ & 21 & $5.3 \%$ \\
\hline \multicolumn{5}{|l|}{ Length of Stay } \\
\hline 1-2 nights & 18 & $4.7 \%$ & 131 & $32.9 \%$ \\
\hline $3-4$ nights & 71 & $18.3 \%$ & 206 & $51.8 \%$ \\
\hline 5-7 nights & 224 & $57.9 \%$ & 51 & $12.8 \%$ \\
\hline More than 7 nights & 74 & $19.1 \%$ & 10 & $2.5 \%$ \\
\hline
\end{tabular}

Note: Totals may not equate to respective Ns due to missing data.

\subsection{Invariance Testing}

Before combining the two samples (timeshare and P2P), measurement invariance was assessed following the principles outlined by Byrne [62]. First, a series of confirmatory factor analyses (CFAs) were performed for the timeshare sample and the P2P sample, separately, to establish baseline models. All analysis was conducted in Mplus v8.2 using the robust maximum likelihood (MLR) estimator. Five rounds of CFA were conducted for the timeshare group and three rounds were conducted for the P2P group, and in addition to the standard goodness-of-fit indices, convergent and discriminant validity were assessed after each round [63]. In both models, four trust items were systematically removed due to average variance extracted (AVE) values below 0.50, which resulted in baseline models that fit the data well for both the timeshare sample $\left(\chi^{2}=551.251(\mathrm{df}=303, p<0.001)\right.$, RMSEA $=0.046,0.040 \leq$ RMSEA CI $_{90} \leq 0.052$, SRMR $=0.053$, CFI $\left.=0.966\right)$ and the P2P sample $\left(\chi^{2}=598.332(\mathrm{df}=303, p<0.001)\right.$, RMSEA $=0.049,0.044 \leq \mathrm{RMSEA} \mathrm{CI}_{90} \leq 0.055$, $\mathrm{SRMR}=0.057, \mathrm{CFI}=0.941)$. In each model, both convergent and discriminant validity were achieved. Thus, configural invariance was established. 
Next, the samples were tested for metric, scalar, and residual invariance (see Table 2). As the MLR estimator was used for all analyses, nested model comparisons were conducted using the Satorra-Bentler scaled chi-square difference test [64]. The timeshare respondents served as the reference group in all invariance models. The results suggested scalar invariance was achieved; thus, the samples were deemed appropriate to combine and utilize in the comparison of the structural models [65].

Table 2. Model fit statistics for tests of measurement invariance.

\begin{tabular}{|c|c|c|c|c|c|c|c|c|c|c|c|}
\hline Model & $\begin{array}{c}\text { MLR } \\
\chi^{2}(\mathrm{df})\end{array}$ & $\begin{array}{l}\text { Scaling } \\
\text { Factor }\end{array}$ & CFI & $\begin{array}{c}\text { RMSEA } \\
(\mathbf{9 0} \% \text { C.I. })\end{array}$ & SRMR & $\begin{array}{c}\text { Model } \\
\text { Comparison }\end{array}$ & $\Delta \chi^{2}(\Delta \mathrm{df})$ & $\Delta \mathrm{CFI}$ & $\triangle$ RMSEA & $\Delta$ SRMR & Decision \\
\hline $\begin{array}{l}\text { M1. Configural } \\
\text { Model a }^{\text {a }}\end{array}$ & $\begin{array}{c}1183.09 \\
(606)\end{array}$ & 1.3012 & 0.950 & $\begin{array}{c}0.049 \\
(0.045-0.053)\end{array}$ & 0.055 & - & - & - & - & - & - \\
\hline $\begin{array}{l}\text { M2. Metric } \\
\text { Model }^{\text {b }}\end{array}$ & $\begin{array}{c}1240.58 \\
(626)\end{array}$ & 1.2975 & 0.947 & $\begin{array}{c}0.050 \\
(0.046-0.054)\end{array}$ & 0.060 & M2 vs. M1 & $59.23 * * *(20)$ & -0.003 & 0.001 & 0.005 & Accept \\
\hline $\begin{array}{l}\text { M3. Scalar } \\
\text { Model }^{c}\end{array}$ & $\begin{array}{c}1337.16 \\
(646)\end{array}$ & 1.2884 & 0.940 & $\begin{array}{c}0.052 \\
(0.048-0.056)\end{array}$ & 0.064 & M3 vs. M2 & $112.74^{* * *}(20)$ & -0.007 & 0.002 & 0.004 & Accept \\
\hline $\begin{array}{l}\text { M4. Residual } \\
\text { Model }^{\mathrm{d}}\end{array}$ & $\begin{array}{c}1532.43 \\
(673)\end{array}$ & 1.3230 & 0.925 & $\begin{array}{c}0.057 \\
(0.053-0.061)\end{array}$ & 0.070 & M4 vs. M3 & $141.62^{* * *}(27)$ & -0.015 & 0.005 & 0.006 & Reject \\
\hline
\end{tabular}

Notes: ${ }^{* * *} p<0.001{ }^{\text {a }}$ No equality constraints, ${ }^{\mathrm{b}}$ Factor loadings constrained to be equal, ${ }^{\mathrm{c}}$ Factor loadings and intercepts constrained to be equal, ${ }^{\mathrm{d}}$ Factor loadings, intercepts, and residuals constrained to be equal.

\subsection{Measurement Model for the Combined Group}

A consolidated measurement model was validated for fit and construct validity. This model fit the data well $\left(\chi^{2}=551.251(\mathrm{df}=303, p<0.001)\right.$, RMSEA $=0.046,0.040 \leq \mathrm{RMSEA}$ $\mathrm{CI90} \leq 0.052, \mathrm{SRMR}=0.053, \mathrm{CFI}=0.966)$. Additionally, all of the standardized factor loadings were above $0.60(p<0.001)$ and the AVE values ranged from 0.576 to 0.858 . Construct reliabilities ranged from 0.764 to 0.960 (see Table 3). The squared correlations between paired constructs were lower than their respective AVEs (see Table 4). Thus, construct validity was confirmed.

Table 3. Convergent validity estimates.

\begin{tabular}{|c|c|c|c|}
\hline Items & $\begin{array}{c}\text { Std. } \\
\text { Loading }\end{array}$ & AVE & CR \\
\hline Amenities & & 0.655 & 0.882 \\
\hline I stay at a TS/P2P accommodation because the property has good amenities & 0.865 & & \\
\hline I stay at a TS/P2P accommodation because the property has nice features & 0.904 & & \\
\hline I stay at a TS/P2P accommodation because the property has nice appliances & 0.652 & & \\
\hline I stay at a TS/P2P accommodation because it is a high-quality property & 0.794 & & \\
\hline Community Belonging & & 0.653 & 0.904 \\
\hline The use of TS/P2P accommodations allows me to be part of a group of likeminded people & 0.811 & & \\
\hline $\begin{array}{l}\text { The use of TS/P2P accommodations allows me to belong to a group of people with similar } \\
\text { interests }\end{array}$ & 0.862 & & \\
\hline Staying at TS/P2P accommodations allows me to turn strangers into friends & 0.774 & & \\
\hline I felt like I was part of the local community when I stayed in TS/P2P accommodations & 0.787 & & \\
\hline Staying at a TS/P2P accommodation made me feel I belong to a special travel community. & 0.803 & & \\
\hline Economic Benefits & & 0.858 & 0.960 \\
\hline Staying at a TS/P2P accommodation saves me money & 0.910 & & \\
\hline Staying at a TS/P2P accommodation helps lower my travel costs & 0.946 & & \\
\hline Staying at TS/P2P accommodations makes travel more affordable & 0.952 & & \\
\hline Staying at TS/P2P accommodations benefits me financially & 0.896 & & \\
\hline Trust & & 0.604 & 0.764 \\
\hline $\begin{array}{l}\text { I trust that the P2P host/TS resort provides enough safeguards to protect me from liability } \\
\text { for damage I am not responsible for. }\end{array}$ & 0.744 & & \\
\hline $\begin{array}{l}\text { TS/P2P accommodations provide a robust and safe environment in which I can use the } \\
\text { services. }\end{array}$ & 0.809 & & \\
\hline
\end{tabular}


Table 3. Cont.

\begin{tabular}{|c|c|c|c|}
\hline Items & $\begin{array}{l}\text { Std. } \\
\text { Loading }\end{array}$ & AVE & CR \\
\hline Vacation Counselor/Host & & 0.730 & 0.890 \\
\hline $\begin{array}{l}\text { Personalized communication by the P2P host/TS resort concierge makes me feel that I am a } \\
\text { unique customer }\end{array}$ & 0.783 & & \\
\hline I believe that communication by the $\mathrm{P} 2 \mathrm{P}$ host/TS resort concierge is customized to my needs & 0.899 & & \\
\hline $\begin{array}{l}\text { Communication by the } \mathrm{P} 2 \mathrm{P} \text { host/TS resort concierge provides me with product and service } \\
\text { recommendations that are tailor-made for me }\end{array}$ & 0.877 & & \\
\hline Satisfaction & & 0.576 & 0.802 \\
\hline TS/P2P accommodations represent the ideal version of a sharing option. & 0.729 & & \\
\hline The last stay at a TS/P2P accommodation fulfilled my expectation. & 0.678 & & \\
\hline Overall, I am satisfied with TS/P2P accommodations & 0.859 & & \\
\hline eWOM & & 0.676 & 0.926 \\
\hline $\begin{array}{l}\text { I mentioned this TS/P2P accommodation to others through online platforms (e.g., } \\
\text { TripAdvisor or Facebook) }\end{array}$ & 0.847 & & \\
\hline $\begin{array}{l}\text { I mentioned this TS/P2P accommodation more frequently than other accommodations I have } \\
\text { stayed at in my online posting (e.g., TripAdvisor or Facebook) }\end{array}$ & 0.884 & & \\
\hline $\begin{array}{l}\text { I would not miss an opportunity to tell others about this TS/P2P accommodation through } \\
\text { online platforms }\end{array}$ & 0.850 & & \\
\hline I mentioned this TS/P2P accommodation in great detail online & 0.847 & & \\
\hline I had only good things to post online about this TS/P2P accommodation & 0.713 & & \\
\hline I was proud to tell others online that I used this TS/P2P accommodation & 0.779 & & \\
\hline
\end{tabular}

Notes: All loadings significant at $p<0.001 ; \mathrm{AVE}=$ average variance extracted; $\mathrm{CR}=$ construct reliability.

Table 4. Correlations.

\begin{tabular}{cccccccc}
\hline & $\mathbf{1}$ & $\mathbf{2}$ & $\mathbf{3}$ & $\mathbf{4}$ & $\mathbf{5}$ & $\mathbf{6}$ & $\mathbf{7}$ \\
\hline Amenities & - & 0.176 & 0.390 & 0.398 & 0.211 & 0.362 & 0.112 \\
Community Belonging & 0.420 & - & 0.448 & 0.562 & 0.615 & 0.355 & 0.396 \\
Economic Benefits & 0.152 & 0.201 & - & 0.206 & 0.219 & 0.489 & 0.128 \\
Trust & 0.631 & 0.316 & 0.454 & - & 0.288 & 0.523 & 0.162 \\
Vacation Counselor/Host & 0.459 & 0.378 & 0.468 & 0.537 & - & 0.349 & 0.332 \\
Satisfaction & 0.602 & 0.596 & 0.699 & 0.723 & 0.591 & - & 0.222 \\
eWOM & 0.334 & 0.629 & 0.358 & 0.402 & 0.576 & 0.471 & - \\
\hline
\end{tabular}

Notes: All correlations are significant. Correlations between constructs are above the diagonal; Interconstruct squared correlations are below the diagonal.

\subsection{Structural Model for the Combined Group}

Overall, the fit indices suggested the hypothesized model was an adequate fit to the data $\left(\chi^{2}=844.826(\mathrm{df}=308, p<0.001)\right.$, RMSEA $=0.047,0.043 \leq \mathrm{RMSEA} \mathrm{CI}_{90} \leq 0.051$, $\mathrm{SRMR}=0.076, \mathrm{CFI}=0.955)$. However, the addition of a direct path from community belonging to eWOM significantly improved model fit $\left(\Delta \mathrm{S}-\mathrm{B} \chi^{2}=188.276 \Delta \mathrm{df}=1, p<0.001\right)$, and therefore this path was retained for all subsequent analysis. The hypothesized effects of amenities ( $\beta=0.15, p<0.001)$, community belonging $(\beta=0.11, p<0.05)$, economic benefits $(\beta=0.40, p<0.001)$, trust $(\beta=0.34, p<0.001)$, and vacation counselor $/$ host $(\beta=0.01$, $p<0.05$ ) on satisfaction were all significant, supporting H1-H5. The effect of satisfaction on eWOM was also significant $(\beta=0.16, p<0.001)$, supporting H6. Finally, the unhypothesized effect of community belonging on eWOM was positive and significant $(\beta=0.55, p<0.001)$. Figure 2a presents the results of the revised structural model. 


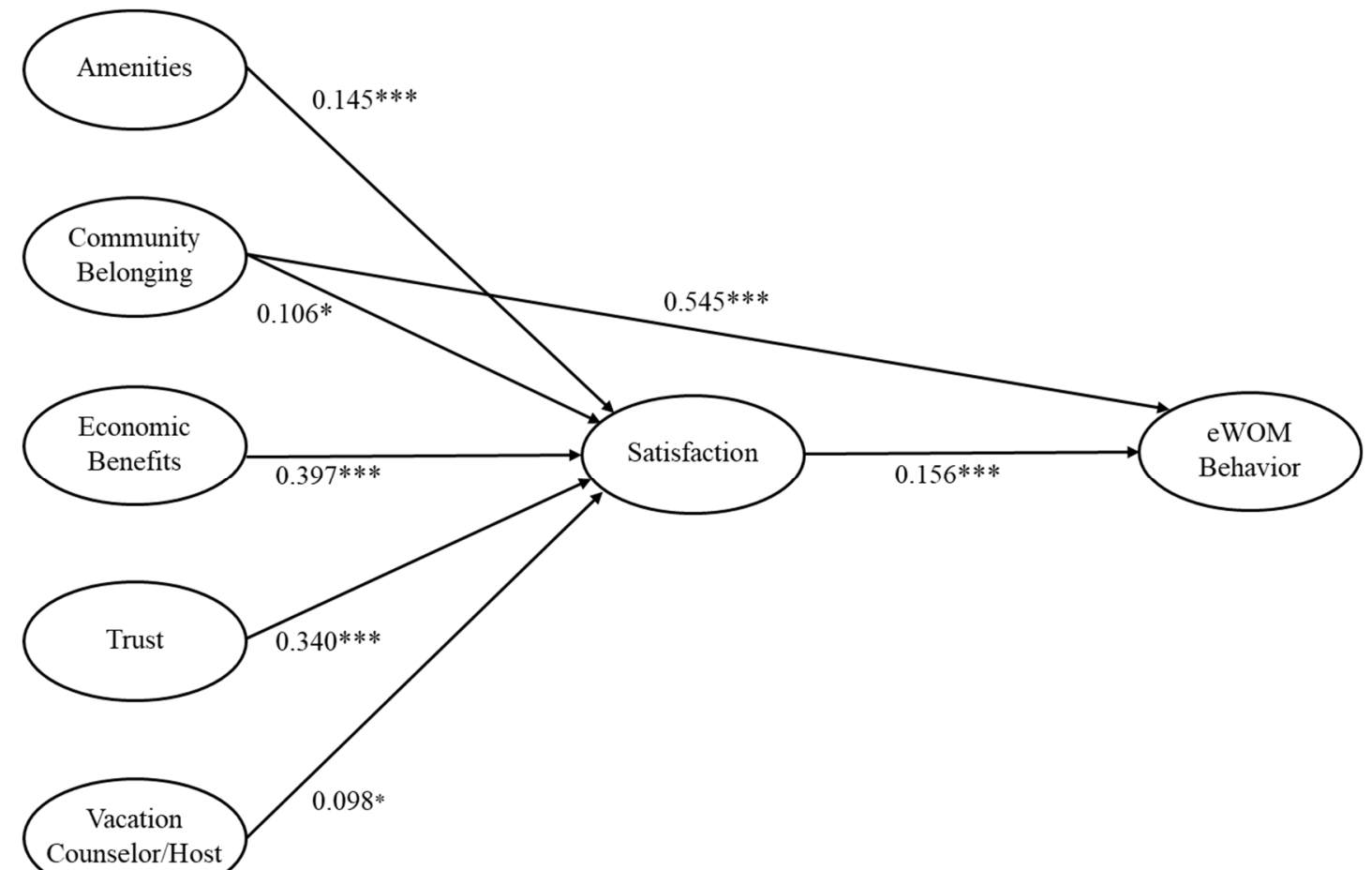

(a) Combined Model

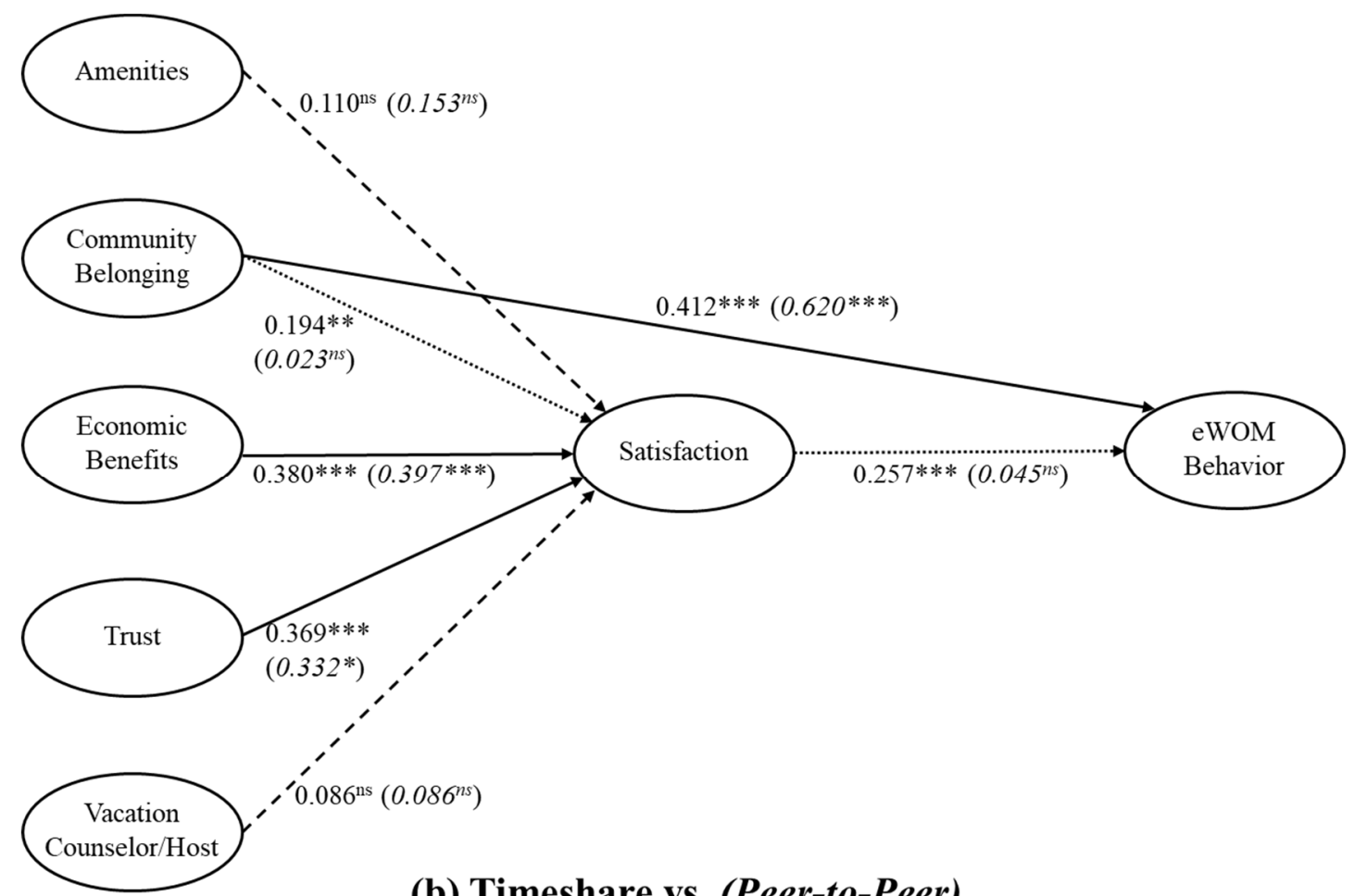

(b) Timeshare vs. (Peer-to-Peer)

Figure 2. Structural model results. Notes: Standardized parameter estimates. $\longrightarrow$ Significant for both groups; $\cdots \rightarrow$ Significant for timeshare only; $\rightarrow$ Not significant. ${ }^{*} p<0.05 ;{ }^{* *} p<0.01$; *** $p<0.001$. ns: not significant.

\subsection{Mediation Analysis for the Combined Group}

The mediating role of satisfaction was tested via $95 \%$ confidence intervals with 5000 bootstrapped samples [66]. Table 5 summarizes the results. All fit indices for the medi- 
ation model were within the ideal range $\left(\chi^{2}=1029.67(\mathrm{df}=307, p<0.001)\right.$, RMSEA $=0.055$, $\left.0.051 \leq \mathrm{RMSEA} \mathrm{CI}_{90} \leq 0.058, \mathrm{SRMR}=0.053, \mathrm{CFI}=0.956\right)$. There were significant indirect effects of amenities, economic benefits, and trust on eWOM through satisfaction; therefore, H7a, H7c, and H7d were supported. Conversely, H7b and H7e were not supported. The indirect effects for community belonging and vacation counselor/host were not significant, as the respective $95 \%$ confidence intervals contained zero.

Table 5. Parameter estimates for indirect effect of satisfaction.

\begin{tabular}{|c|c|c|c|c|c|c|c|c|c|}
\hline \multicolumn{10}{|l|}{ Combined Model } \\
\hline \multirow{2}{*}{ Indirect Paths } & \multirow{2}{*}{\multicolumn{2}{|c|}{ Estimate }} & \multirow{2}{*}{\multicolumn{2}{|c|}{ Standard Error }} & \multicolumn{4}{|c|}{ 95\% Confidence Interval } & \multirow{2}{*}{ Supported? } \\
\hline & & & & & \multicolumn{2}{|c|}{ Low } & \multicolumn{2}{|c|}{ High } & \\
\hline \multirow{2}{*}{$\begin{array}{l}\text { H7a. Amenities } \rightarrow \text { Satisfaction } \rightarrow \text { eWOM } \\
\text { H7b. Community Belonging } \rightarrow \text { Satisfaction } \\
\rightarrow \text { eWOM }\end{array}$} & \multicolumn{2}{|c|}{0.037} & \multicolumn{2}{|c|}{0.018} & \multicolumn{2}{|c|}{0.010} & \multicolumn{2}{|c|}{0.081} & Yes \\
\hline & \multicolumn{2}{|c|}{0.024} & \multicolumn{2}{|c|}{0.014} & & & \multicolumn{2}{|c|}{0.060} & No \\
\hline $\begin{array}{l}\text { H7c. Economic Benefits } \rightarrow \text { Satisfaction } \rightarrow \\
\text { eWOM }\end{array}$ & \multicolumn{2}{|c|}{0.076} & \multicolumn{2}{|c|}{0.023} & \multicolumn{2}{|c|}{0.033} & & & Yes \\
\hline H7d. Trust $\rightarrow$ Satisfaction $\rightarrow$ eWOM & \multicolumn{2}{|c|}{0.094} & \multicolumn{2}{|c|}{0.032} & \multicolumn{2}{|c|}{0.042} & \multicolumn{2}{|c|}{0.169} & Yes \\
\hline $\begin{array}{l}\text { H7e. Vacation Counselor/Host } \rightarrow \\
\text { Satisfaction } \rightarrow \text { eWOM }\end{array}$ & \multicolumn{2}{|c|}{0.015} & \multicolumn{2}{|c|}{0.015} & \multicolumn{2}{|c|}{0.000} & \multicolumn{2}{|c|}{0.061} & No \\
\hline \multicolumn{10}{|l|}{ Moderating Effect of Accommodation Type } \\
\hline \multirow{3}{*}{ Indirect Paths } & \multicolumn{4}{|c|}{ Timeshare } & \multicolumn{4}{|c|}{ Peer-to-Peer } & \\
\hline & \multirow{2}{*}{ Est. } & \multirow{2}{*}{ S.E. } & \multicolumn{2}{|c|}{ 95\% C.I. } & \multirow{2}{*}{ Est. } & \multirow{2}{*}{ S.E. } & 95 & & Supported? \\
\hline & & & Low & High & & & Low & High & \\
\hline H8a. Amenities $\rightarrow$ Satisfaction $\rightarrow$ eWOM & 0.044 & 0.030 & -0.003 & -0.116 & 0.011 & 0.019 & -0.015 & 0.071 & No \\
\hline $\begin{array}{l}\text { H8b. Community Belonging } \rightarrow \text { Satisfaction } \\
\rightarrow \text { eWOM }\end{array}$ & 0.075 & 0.033 & 0.026 & 0.161 & 0.001 & 0.009 & -0.009 & 0.035 & Yes \\
\hline $\begin{array}{l}\text { H8c. Economic Benefits } \rightarrow \text { Satisfaction } \rightarrow \\
\text { eWOM }\end{array}$ & 0.110 & 0.031 & 0.055 & 0.177 & 0.027 & 0.038 & -0.042 & 0.109 & Yes \\
\hline H8d. Trust $\rightarrow$ Satisfaction $\rightarrow$ eWOM & 0.177 & 0.056 & 0.087 & 0.306 & 0.025 & 0.040 & -0.041 & 0.126 & Yes \\
\hline $\begin{array}{l}\text { H8e. Vacation Counselor/Host } \rightarrow \\
\text { Satisfaction } \rightarrow \text { eWOM }\end{array}$ & 0.030 & 0.027 & -0.010 & 0.098 & 0.006 & 0.015 & -0.007 & 0.061 & No \\
\hline
\end{tabular}

Note: Estimates of indirect effects and 95\% confidence intervals obtained via 5000 bootstrapped samples.

\subsection{Group Differences: Timeshare vs. P2P}

The moderating role of accommodation type (timeshare vs. P2P) was tested via multiple-group analysis, in which structural invariance is used to test whether the parameter estimates across the two groups are statistically significant [64]. The unconstrained path model, which allowed all parameters to vary between the two groups, provided an adequate fit to the data $\left(\chi^{2}=1775.023(\mathrm{df}=654, p<0.001), \mathrm{RMSEA}=0.066,0.062 \leq \mathrm{RMSEA} \mathrm{CI}_{90}\right.$ $\leq 0.070, \mathrm{SRMR}=0.069, \mathrm{CFI}=0.931)$, as did the invariant path model $\left(\chi^{2}=1797.695(\mathrm{df}=661\right.$, $p<0.001)$, RMSEA $\left.=0.066,0.063 \leq \mathrm{RMSEA} \mathrm{CI}_{90} \leq 0.070, \mathrm{SRMR}=0.073, \mathrm{CFI}=0.930\right)$. However, a log-likelihood chi-square difference test indicated constraining the structural parameters to be equal resulted in a statistically significant worsening of overall model fit $\left(\Delta \chi^{2}=22.672 \Delta \mathrm{df}=7, p=0.01\right)$. In the unconstrained model, group-specific $\chi^{2}$ values revealed the timeshare model provided a better fit to the data $\left(\chi^{2}\right.$ Timeshare $=773.44$; $\chi^{2}{ }_{\mathrm{P} 2 \mathrm{P}}=1001.583$ ).

The results also revealed a significant moderating effect of accommodation type on three of the hypothesized indirect effects: (H8b) community belonging $\rightarrow$ satisfaction $\rightarrow$ eWOM; (H8c) economic benefits $\rightarrow$ satisfaction $\rightarrow$ eWOM; and (H8d) trust $\rightarrow$ satisfaction $\rightarrow$ eWOM (see Figure $2 \mathrm{~b}$ and Table 5 ). The primary difference driving the moderating effect was the insignificant relationship between sharing economy lodging satisfaction and eWOM ( $p=0.47)$ for the P2P group, which meant satisfaction did not mediate the effects of any of the five determinants (amenities, community belonging, economic benefits, trust, or vacation counselor/host) on eWOM. However, moderation was not supported for the remaining indirect paths: (H8a) amenities $\rightarrow$ satisfaction $\rightarrow$ eWOM and (H8e) vacation counselor/host $\rightarrow$ satisfaction $\rightarrow$ eWOM. Although the relationship between satisfaction 
and eWOM was significant for the timeshare group $(p<0.001)$, the effects of amenities ( $\beta=0.11, p=0.099)$ and vacation counselor $(\beta=0.09, p=0.187)$ on satisfaction were not significant; thus, the respective indirect effects were insignificant for both groups.

\section{Discussion}

This study examined the differential effects of five known determinants of satisfaction on subsequent electronic word-of-mouth (eWOM) behavior for the users of two types of sharing economy lodging products: timeshare stays and $\mathrm{P} 2 \mathrm{P}$ accommodations. Our results from the combined timeshare/P2P sample provide confirmation of previous studies that amenities, community belonging, economic benefits, trust, and vacation counselor/host each have a positive effect on satisfaction and also revealed an unexpected direct effect of community belonging on eWOM behavior. Satisfaction was further identified as the underlying mechanism linking amenities, economic benefits, and trust with eWOM. Finally, and most critically, this mechanism functioned differently based on accommodation type. For timeshare users, satisfaction mediated the effects of community belonging, economic benefits, and trust on eWOM, while for P2P users, no linking mechanism was found, as satisfaction had no effect on eWOM. These findings reveal deeper insight into timeshare stays' role in the sharing economy and offer future research opportunities.

The contribution of this research is threefold. First, this study extends both satisfaction and eWOM literature by highlighting the mediating role of satisfaction relative to sharing economy accommodations, which has not been previously explored. It also suggests that this is specific to timeshare stays, which provides an opportunity for timeshare developers to exploit. Second, this study extends the antecedents of eWOM behavior with a newly found direct path from community belonging. Third, this research advances sharing economy literature to include timeshare stays and adds to the body of knowledge of the timeshare segment within the lodging industry.

The study sought to answer the primary research objective of the differential effects of known determinants of satisfaction on subsequent eWOM behavior in collaborative consumption and the sharing economy related to timeshare accommodations and P2P accommodations. The literature suggested that satisfaction has a relationship with eWOM [55-59]. The study supported this finding in the timeshare context but not the P2P accommodation context. It was unexpected for there to not be a relationship between satisfaction and eWOM in the P2P context. This was a unique finding in the study that merits further research. The study also found that community belonging leads to eWOM in both timeshare and $\mathrm{P} 2 \mathrm{P}$ accommodation stays. This was a groundbreaking finding not previously mentioned in literature.

The study considered three secondary research objectives. The first was to test the effects of five known determinants of satisfaction in the specific context of timeshare stays and P2P accommodation sharing. The literature identified the following determinants of satisfaction: amenities [33], community belonging [27,33], economic benefits [27,33], trust [27], and vacation counselor [51,52]. The most important determinants revealed by the study were community belonging, economic benefits, and trust for timeshare stays and economic benefits and trust for P2P accommodation stays.

The next secondary research objective was to examine the mediating role of satisfaction between these determinants and eWOM. The literature supported satisfaction as a mediator in previous studies $[60,61]$. The results of this study revealed indirect paths for amenities, economic benefits, and trust suggesting satisfaction as a mediator to eWOM for these specific determinants. Recent literature supports the findings of this study related to economic benefits and amenities as determinants of satisfaction and its effect on eWOM with hotel stays using online reviews. Kitsios [67] explored user-generated content of hotel guests demonstrating that satisfaction with amenities (room/services) impacted eWOM. Additional studies of hotel reviews found that satisfaction with economic benefits and amenities influenced eWOM (Ban et al. [68], Berezina et al. [69], Manolitzas et al. [70], Zhao [71]). These articles highlight the significance of this study to lay the foundation 
for exploring the effect of satisfaction on eWOM behavior related to sharing economy accommodation stays at timeshare and P2P accommodations.

The final secondary research objective was to assess the moderating role of accommodation type. Previous studies had compared P2P accommodations and hotels $[15,44]$ but not timeshare stays. The findings indicated a moderating effect of accommodation type for community belonging and satisfaction. Thus, differences in accommodation type resulted in a different outcome for community belonging and satisfaction.

\subsection{Theoretical Implications}

To promote further theoretical development related to sharing economy accommodations, this study examined determinants of satisfaction and eWOM within the framework of collaborative consumption theory. Collaborative consumption has evolved from the broad definition of sharing a product together [26] to gifting and sharing [1] to Belk's [25] (p. 1597) more concise definition of "people coordinating the acquisition and distribution of a resource for a fee or other compensation". This definition broadly describes the sharing economy to encompass P2P exchanges as well as business-to-consumer exchanges such as car-sharing services [27].

With the hypotheses of the combined group of timeshares and P2P illustrating amenities, community belonging, economic benefits, trust, and vacation counselor/host having a positive impact on satisfaction, and satisfaction having a positive effect on eWOM, collaborative consumption theory is further supported. Hamari [21] noted the economic benefits of a less expensive alternative that collaborative consumption provides. Trust in P2P exchanges was considered to be a foundational tenet of collaborative consumption [1]. The authenticity provided by vacation counselors/hosts was found to a be driver in collaborative consumption [28].

We also endeavored to advance the timeshare literature in the realm of the sharing economy based on collaborative consumption theory [25]. Möhlmann's [27] study utilized collaborative consumption theory by comparing consumer-to-consumer and business-toconsumer transactions involving the temporary, non-ownership use of goods. We submit that timeshares and P2P accommodations are similar in the sharing economy context and collaborative consumption related to amenities and vacation counselor/host, as a moderating difference of accommodation type was not found. Further, Belk asserted "if a sense of community and aggregate extended self were to emerge among members of a time-share condo, it would be a sharing/pseudo-sharing hybrid" [72] (p. 12). This study found that community belonging in the timeshare context played an integral role in the satisfaction of the timeshare experience. As a result, it could be said that this study advances the role of timeshare accommodations in the sharing economy lodging context and collaboration consumption theory [72].

\subsection{Practical Implications}

In the highly competitive lodging industry, understanding the significance of managing eWOM behavior may create a competitive advantage [20]. The results from this study inform lodging industry marketing practitioners on factors such as community belonging, economic benefits, and trust, which directly influence satisfaction and indirectly influence eWOM behavior, so they may be incorporated into marketing communication plans in order to promote eWOM behavior and ultimately sales [20]. This study revealed that P2P accommodations had an advantage of economic benefits on satisfaction and community belonging on eWOM over timeshare stays. On the other hand, timeshare stays had an advantage over $\mathrm{P} 2 \mathrm{P}$ accommodation stays in relation to trust and community belonging affecting satisfaction and satisfaction influencing eWOM. Practitioners are encouraged to utilize these actionable findings to target areas in need of improvement and to continue to build on areas of strength. For example, given the P2P advantage of economic benefits, timeshares are encouraged to promote the value of their accommodations, particularly timeshare rentals that are offered by $90 \%$ of timeshare resorts and compete directly on P2P 
accommodation websites such as Airbnb and Vrbo [7]. In addition to providing revenue, timeshare renters provide a source of potential timeshare tours and sales.

Further, in the timeshare context, studies have shown that eWOM is influential in generating leads and minimizing rescissions and exits [73,74]. In the P2P context, recommendations from other consumers have been shown to influence participation in the sharing economy [29]. As a result, unveiling factors such as satisfaction and community belonging that directly impact eWOM is beneficial for the lodging industry as a whole. Moreover, while fostering community belonging is important for both types of accommodation, this study suggests that it may be more essential for timeshares considering its positive influence on both satisfaction and eWOM. Designing organized activities and creating spaces for interaction can help to increase the sense of community among timeshare owners and guests. The findings reinforce the importance of belonging related to "club" and "membership" signals in timeshare sales and marketing positioning. In addition, creating online groups can facilitate continual community belonging by sharing their accommodation stay experiences.

In the P2P context, Tussyadiah's [33] study found that community belonging did not affect satisfaction overall when renting an entire apartment or home, but when renting a room where the host resided, community belonging affected the overall satisfaction. A recent study by Zhu et al. [75] asserted that a feeling of home or community belonging is highly contingent upon the presence of the host. This may indicate a greater emphasis needing to be placed on the host's involvement in creating community belonging.

\subsection{Limitations and Future Research}

While our findings have relevant implications, our study is not without limitations. This study was limited to respondents in the U.S. and owners from one particular timeshare company, and while the respondent population was representative of the larger industry population, the findings may not be generalizable. Future research may broaden the sampling frame to include additional sharing economy vendors as new companies enter the market, as well as additional countries. A non-probability sampling technique was also utilized to collect data, as respondents self-selected to participate in the study, which further limits generalizability. An additional limitation is that this paper focused on the consumers' experiences with sharing economy accommodations and not the booking platform. Further, the study did not include eWOM on a user-generated content platform. Instead, the survey relied on user recall for past behavior, which is subject to response bias.

Our findings also offer opportunities for future research. First, as community belonging was identified as the strongest predictor of eWOM, more research is recommended about this relationship. Second, qualitative research is suggested to discover why the vacation counselor/host was rendered nonsignificant as a determinant of satisfaction for both the timeshare owners and the P2P accommodation users, and in the P2P context to better understand the relationship between satisfaction and eWOM. Third, future research may be conducted on user-generated content platforms to ascertain eWOM related to timeshare and P2P accommodation stays. Fourth, the model could be extended prior to the accommodation stay to include the booking experience and post stay to evaluate the effect of eWOM on loyalty.

Author Contributions: Conceptualization, J.R. and A.F.; methodology, M.O.; validation, M.O. and J.R.; formal analysis, M.O. and J.R.; data curation, J.R. and M.O.; writing-original draft preparation, J.R.; writing-review and editing, J.R., M.O., A.F., A.M.G. and H.R. All authors have read and agreed to the published version of the manuscript.

Funding: This research received no external funding.

Institutional Review Board Statement: The study was conducted according to the guidelines of the Declaration of Helsinki and was approved by the Institutional Review Board of University of Central Florida (protocol code sbe-18-14448 10/18/18). 
Informed Consent Statement: Informed consent was obtained from all subjects involved in the study.

Data Availability Statement: The data presented in this study are available on request from the corresponding author. In accordance with consent provided by participants regarding data management, the data are not publicly available.

Conflicts of Interest: The authors declare no conflict of interest.

\section{References}

1. Botsman, R.; Rogers, R. What's Mine Is Yours: The Rise of Collaborative Consumption; Harper Business: New York, NY, USA, 2010.

2. Hossain, M. Sharing economy: A comprehensive literature review. Int. J. Hosp. Manag. 2020, 87, 90-110. [CrossRef]

3. Lamberton, C.P.; Rose, R.L. When is ours better than mine? A framework for understanding and altering participation in commercial sharing systems. J. Mark. 2012, 76, 109-125.

4. Altinay, L.; Taheri, B. Emerging themes and theories in the sharing economy: A critical note for hospitality and tourism. Int. J. Contemp. Hosp. Manag. 2018, 31, 180-193. [CrossRef]

5. Bardhi, F.; Eckhardt, G.M. Access-based consumption: The case of car sharing. J. Consum. Res. 2012, 39, 881-898. [CrossRef]

6. Dredge, D.; Gyimóthy, S. The collaborative economy and tourism: Critical perspectives, questionable claims and silenced voices. Tour. Recreat. Res. 2015, 40, 286-302.

7. ARDA.org. Available online: https://www.arda.org/news-communications/timeshare-industry-basics/us-timeshare-industrynumbers (accessed on 13 October 2021).

8. ARDA. Timeshare Industry Resource Manual; American Resort Development Association's International Foundation: Washington, DC, USA, 2014.

9. Penela, D.; Morais, A.; Gregory, A. An analytical inquiry on timeshare research: A continuously growing segment in the hospitality industry. Int. J. Hosp. Manag. 2019, 76, 132-151. [CrossRef]

10. Eckhardt, G.M.; Houston, M.B.; Jiang, B.; Lamberton, C.; Rindfleisch, A.; Zervas, G. Marketing in the sharing economy. J. Mark. 2019, 83, 5-27. [CrossRef]

11. Kuhzady, S.; Seyfi, S.; Béal, L. Peer-to-peer (P2P) accommodation in the sharing economy: A review. Curr. Issues Tour. 2020, 1-16. [CrossRef]

12. Mody, M.A.; Hanks, L.; Cheng, M. Sharing economy research in hospitality and tourism: A critical review using bibliometric analysis, content analysis and a quantitative systematic literature review. Int. J. Contemp. Hosp. Manag. 2021, 33, 1711-1745. [CrossRef]

13. Prayag, G.; Ozanne, L.K. A systematic review of peer-to-peer (P2P) accommodation sharing research from 2010 to 2016 : Progress and prospects from the multi-level perspective. J. Hosp. Mark. Manag. 2018, 27, 649-678. [CrossRef]

14. Gregory, A.; Weinland, J. Forty years of timeshare research: A synthesis of literature. Int. J. Contemp. Hosp. Manag. 2016, 28, 438-470. [CrossRef]

15. Tussyadiah, I.P.; Zach, F.J. Hotels vs. Peer-to-Peer Accommodation Rentals: Text Analytics of Consumer Reviews in Portland, Oregon. 2015. Available online: https:/ / ssrn.com/abstract=2594985 (accessed on 13 October 2021).

16. Chen, Y.; Xie, K. Consumer valuation of Airbnb listings: A hedonic pricing approach. Int. J. Contemp. Hosp. Manag. 2017, 29, 2405-2424. [CrossRef]

17. Dann, D.; Teubner, T.; Weinhardt, C. Poster child and guinea pig-insights from a structured literature review on Airbnb. Int. J. Contemp. Hosp. Manag. 2018, 31, 427-473. [CrossRef]

18. Dogru, T.; Mody, M.; Suess, C. Adding evidence to the debate: Quantifying Airbnb's disruptive impact on ten key hotel markets. Tour. Manag. 2019, 72, 27-38. [CrossRef]

19. Blal, I.; Singal, M.; Templin, J. Airbnb's effect on hotel sales growth. Int. J. Hosp. Manag. 2018, 73, 85-92. [CrossRef]

20. Litvin, S.W.; Goldsmith, R.E.; Pan, B. Electronic word-of-mouth in hospitality and tourism management. Tour. Manag. 2008, 29, 458-468. [CrossRef]

21. Hamari, J.; Sjöklint, M.; Ukkonen, A. The sharing economy: Why people participate in collaborative consumption. J. Assoc. Inf. Sci. Technol. 2016, 67, 2047-2059. [CrossRef]

22. Pizam, A. Peer-to-peer travel: Blessing or blight? Int. J. Hosp. Manag. 2014, 38, 118-119. [CrossRef]

23. ARDA. State of the Vacation Timeshare Industry; American Resort Development Association: Washington, DC, USA, 2018.

24. Belk, R. Sharing. J. Consum. Res. 2010, 36, 715-734. [CrossRef]

25. Belk, R. You are what you can access: Sharing and collaborative consumption online. J. Bus. Res. 2014, 67, 1595-1600. [CrossRef]

26. Felson, M.; Speath, J. Community structure and collaborative consumption. Am. Behav. Sci. 1978, 41, 614-624. [CrossRef]

27. Möhlmann, M. Collaborative consumption: Determinants of satisfaction and the likelihood of using a sharing economy option again. J. Consum. Behav. 2015, 14, 193-207. [CrossRef]

28. Tussyadiah, I.P. An Exploratory Study on Drivers and Deterrents of Collaborative Consumption in Travel. In Information $\mathcal{E}$ Communication Technologies in Tourism; Springer: Cham, Switzerland, 2015; pp. 817-830. 
29. Owyang, J. Sharing Is the New Buying, Winning in the Collaborative Economy. 2014. Available online: http://www.webstrategist.com/blog/2014/03/03/report-sharing-is-the-new-buying-winning-in-the-collaborative-economy/ (accessed on 5 March 2018).

30. Bellm, B. Vacation rentals: Breathing new life into unsold/vacation Timeshares. Developments Magazine, September 2012, pp. 22-24.

31. Xu, F.; La, L.; Zhen, F.; Lobsang, T.; Huang, C. A data-driven approach to guest experiences and satisfaction in sharing. J. Travel Tour. Mark. 2019, 36, 484-496. [CrossRef]

32. Shin, H.W.; Fan, A.; Lehto, X. Peer-to-peer accommodation: A meta-analysis of factors affecting customer satisfaction and loyalty. Int. J. Tour. Res. 2021, 23, 581-596. [CrossRef]

33. Tussyadiah, I.P. Factors of satisfaction and intention to use peer-to-peer accommodation. Int. J. Hosp. Manag. 2016, 55, 70-80. [CrossRef]

34. Gregory, A.M.; Parsa, H.G.; Nusair, K.; Kwun, D.J.; Putrevu, S. Examining the effects of vacation ownership product attributes on customer satisfaction: An investigation of product purchase and use. Int. J. Contemp. Hosp. Manag. 2015, 27, 52-70. [CrossRef]

35. Heo, C.Y.; Hyun, S.S. Do luxury room amenities affect guests' willingness to pay? Int. J. Hosp. Manag. 2015, 46, 161-168. [CrossRef]

36. Guttentag, D. Airbnb: Disruptive innovation and the rise of an informal tourism accommodation sector. Curr. Issues Tour. 2015, 18, 1192-1217. [CrossRef]

37. Luo, Y.; Tang, R.L. Understanding hidden dimensions in textual reviews on Airbnb: An application of modified latent aspect rating analysis (LARA). Int. J. Hosp. Manag. 2019, 80, 144-154. [CrossRef]

38. Upchurch, R.S.; Gruber, K. The evolution of a sleeping giant: Resort timesharing. Int. J. Hosp. Manag. 2002, 21, 211-225. [CrossRef]

39. Upchurch, R.S.; DiPietro, R.B.; McLeod, B. Timeshare owner preferences-An analysis of program and service relationships during recessionary times. FIU Rev. 2010, 28, 1-20.

40. Sundararajan, A. Commentary: The twilight of brand and consumerism? Digital trust, cultural meaning, and the quest for connection in the sharing economy. J. Mark. 2019, 83, 32-35.

41. Tussyadiah, I.P.; Pesonen, J. Impacts of peer-to-peer accommodation use on travel patterns. J. Travel Res. 2016, 55, 1022-1040. [CrossRef]

42. Mody, M.A.; Suess, C.; Lehto, X. The accommodation experiencescape: A comparative assessment of hotels and Airbnb. Int. J. Contemp. Hosp. Manag. 2017, 29, 2377-2404. [CrossRef]

43. Sparks, B.; Butcher, K.; Pan, G. Understanding customer-derived value in the timeshare industry. Cornell Hotel Restaur. Adm. Q. 2007, 48, 28-45. [CrossRef]

44. Zervas, G.; Proserpio, D.; Byers, J.W. The rise of the sharing economy: Estimating the impact of Airbnb on the hotel industry. J. Mark. Res. 2017, 54, 687-705. [CrossRef]

45. Poon, K.Y.; Huang, W.J. Past experience, traveler personality and tripographics on intention to use Airbnb. Int. J. Contemp. Hosp. Manag. 2017, 29, 2425-2443. [CrossRef]

46. Powanga, A.; Powanga, L. An economic analysis of a timeshare ownership. J. Retail Leis. Prop. 2008, 7, 69-83. [CrossRef]

47. Jiang, Y.; Balaji, M.S.; Jha, S. Together we tango: Value facilitation and customer participation in Airbnb. Int. J. Hosp. Manag. 2019, 82, 169-180. [CrossRef]

48. Rotter, J.B. A new scale for the measurement of interpersonal trust. J. Personal. 1967, 35, 651-665. [CrossRef]

49. So, K.K.F.; Oh, H.; Min, S. Motivations and constraints of Airbnb consumers: Findings from a mixed-methods approach. Tour. Manag. 2018, 67, 224-236. [CrossRef]

50. Kaufman, T.J.; Curtis, C.; Upchurch, R.S. Timeshare brand affiliation impacts. Int. J. Built Environ. Asset Manag. 2011, 1, 4-13. [CrossRef]

51. Ju, Y.; Back, K.J.; Choi, Y.; Lee, J.S. Exploring Airbnb service quality attributes and their asymmetric effects on customer satisfaction. Int. J. Hosp. Manag. 2019, 77, 342-352. [CrossRef]

52. Wang, C.R.; Jeong, M. What makes you choose Airbnb again? An examination of users' perceptions toward the website and their stay. Int. J. Hosp. Manag. 2018, 74, 162-170.

53. Halstead, D.; Page, T.J. The effects of satisfaction and complaining behavior on consumer repurchase intentions. J. Consum. Satisf. Dissatisf. Complain. Behav. 1992, 5, 1-11.

54. Kimmel, A.; Kitchen, P. Word of mouth and social media. J. Mark. Commun. 2014, 20, 2-4. [CrossRef]

55. Yen, C.; Tang, C. Hotel attribute performance, eWOM motivations, and media choice. Int. J. Hosp. Manag. 2015, 46, 79-88. [CrossRef]

56. de Matos, C.A.; Rossi, C.V. Word-of-mouth communications in marketing: A meta-analytic review of the antecedents and moderators. J. Acad. Mark. Sci. 2008, 36, 578-596. [CrossRef]

57. Lawton, L.; Weaver, D.; Faulkner, B. Customer satisfaction in the Australian timeshare industry. J. Travel Res. 1998, 37, 30-38. [CrossRef]

58. Johnson, A.G.; Neuhofer, B. Airbnb-an exploration of value co-creation experiences in Jamaica. Int. J. Contemp. Hosp. Manag. 2017, 29, 2361-2376. [CrossRef]

59. Camilleri, J.; Neuhofer, B. Value co-creation and co-destruction in the Airbnb sharing economy. Int. J. Contemp. Hosp. Manag. 2017, 29, 2322-2340. [CrossRef] 
60. Ha, Y.; Im, H. Role of web site design quality in satisfaction and word of mouth generation. J. Serv. Manag. 2012, 23, 79-96. [CrossRef]

61. Rizal, H.; Yussof, S.; Amin, H.; Chen-Jung, K. EWOM towards homestays lodging: Extending the information system success model. J. Hosp. Tour. Technol. 2018, 9, 94-108. [CrossRef]

62. Byrne, B.M. Structural Equation Modeling with Mplus: Basic Concepts, Applications, and Programming; Routledge: New York, NY, USA, 2012.

63. Hair, J.F.; Black, W.C.; Babin, B.J.; Anderson, R.E. Multivariate Data Analysis, 7th ed.; Prentice Hall: Upper Saddle River, NJ, USA, 2010.

64. Muthén, L.K.; Muthén, B.O. Mplus User's Guide, 8th ed.; Muthén \& Muthén: Los Angeles, CA, USA, $1998-2017$.

65. Putnick, D.L.; Bornstein, M.H. Measurement invariance conventions and reporting: The state of the art and future directions for psychological research. Dev. Rev. 2016, 41, 71-90. [CrossRef] [PubMed]

66. Asparouhov, T.; Muthén, B. Structural equation models and mixture models with continuous nonnormal skewed distributions. Struct. Equ. Model. Multidiscip. J. 2016, 23, 1-19. [CrossRef]

67. Kitsios, F.; Kamariotou, M.; Karanikolas, P.; Grigoroudis, E. Digital marketing platforms and customer satisfaction: Identifying eWom using big data and text mining. Appl. Sci. 2021, 11, 8032. [CrossRef]

68. Ban, H.J.; Choi, H.; Choi, E.K.; Lee, S.; Kim, H.S. Investigating key attributes in experience and satisfaction of hotel customer using online review data. Sustainability 2019, 11, 6570. [CrossRef]

69. Berezina, K.; Bilgihan, A.; Cobanoglu, C.; Okumus, F. Understanding satisfied and dissatisfied hotel customers: Text mining of online hotel reviews. J. Hosp. Mark. Manag. 2016, 25, 1-24. [CrossRef]

70. Manolitzas, P.; Glaveli, N.; Palamas, S.; Talias, M.; Grigoroudis, E. Hotel guests' demanding level and importance of attribute satisfaction ratings: An application of MUltiple criteria Satisfaction Analysis on TripAdvisor's hotel guests ratings. Curr. Issues Tour. 2021, 1-6. [CrossRef]

71. Zhao, S. Thumb Up or Down? A Text? Mining Approach of Understanding Consumers through Reviews. Decis. Sci. 2021, 52, 699-719. [CrossRef]

72. Belk, R. Sharing versus pseudo-sharing in Web 2.0. Anthropologist 2014, 18, 7-23. [CrossRef]

73. Sparks, B.; Bradley, G.; Jennings, G. Consumer value and self-image congruency at different stages of timeshare ownership. Tour. Manag. 2011, 32, 1176-1185. [CrossRef]

74. Upchurch, R.S.; Rompf, P. Postpurchase behavior: A case study into a vacation club product. Tour. Anal. 2006, 11, 45-59. [CrossRef]

75. Zhu, Y.; Cheng, M.; Wang, J.; Ma, L.; Jiang, R. The construction of home feeling by Airbnb guests in the sharing economy: A semantics perspective. Ann. Tour. Res. 2019, 75, 308-321. [CrossRef] 